Meta

Journal des traducteurs

Translators' Journal

\title{
Literary Transfer between Peripheral Languages: A Production of Culture Perspective
}

\section{Ran Hacohen}

Volume 59, numéro 2, août 2014

URI : https://id.erudit.org/iderudit/1027477ar

DOI : https://doi.org/10.7202/1027477ar

Aller au sommaire du numéro

\section{Éditeur(s)}

Les Presses de l’Université de Montréal

\section{ISSN}

0026-0452 (imprimé)

1492-1421 (numérique)

Découvrir la revue

Citer cet article

Hacohen, R. (2014). Literary Transfer between Peripheral Languages: A Production of Culture Perspective. Meta, 59(2), 297-309.

https://doi.org/10.7202/1027477ar
Résumé de l'article

À titre d'exemple du transfert culturel entre deux langues mineures, les traductions littéraires de l'hébreu vers le néerlandais et vice versa, effectuées entre 1991 et 2010, ont fait l'objet d'une étude fondée sur la perspective de la production culturelle (Peterson et Anand 2004). Selon cette étude, 138 ouvrages hébreux ont été traduits en néerlandais au cours de cette période, contre seulement 52 ouvrages néerlandais traduits en hébreu. Ces données ont été analysées selon les genres littéraires, la productivité des traducteurs et le nombre de livres traduits par auteur. L'analyse révèle ainsi une similitude dans la répartition des genres, dans les deux sens. On dénote néanmoins une différence significative en termes de productivité (la productivité moyenne des traducteurs néerlandais étant plus de deux fois supérieure à celle de leurs homologues hébreux) et du nombre d'ouvrages traduits par auteur (le double sur le marché néerlandais). Ces écarts s'expliquent notamment par les disparités entre le contexte du marché de la traduction en Israël et celui des Pays-Bas et de la Belgique, mais aussi par la prédominance des subventions des États néerlandais et de la Communauté flamande pour la traduction dans les deux sens, bien que la politique de subvention ne soit pas la même pour chaque sens. De fait, il semblerait que l'on puisse tirer des conclusions importantes par l'analyse de facteurs tels que la taille et la répartition du corpus en ce qui a trait aux conditions de travail et aux subventions gouvernementales.
Ce document est protégé par la loi sur le droit d'auteur. L’utilisation des services d'Érudit (y compris la reproduction) est assujettie à sa politique d'utilisation que vous pouvez consulter en ligne.

https://apropos.erudit.org/fr/usagers/politique-dutilisation/ 


\title{
Literary Transfer between Peripheral Languages: A Production of Culture Perspective
}

\author{
RAN HACOHEN \\ Tel Aviv University, Tel Aviv, Israel \\ ranhacohen@gmail.com
}

\begin{abstract}
RÉSUMÉ
À titre d'exemple du transfert culturel entre deux langues mineures, les traductions littéraires de l'hébreu vers le néerlandais et vice versa, effectuées entre 1991 et 2010, ont fait l'objet d'une étude fondée sur la perspective de la production culturelle (Peterson et Anand 2004). Selon cette étude, 138 ouvrages hébreux ont été traduits en néerlandais au cours de cette période, contre seulement 52 ouvrages néerlandais traduits en hébreu. Ces données ont été analysées selon les genres littéraires, la productivité des traducteurs et le nombre de livres traduits par auteur. L'analyse révèle ainsi une similitude dans la répartition des genres, dans les deux sens. On dénote néanmoins une différence significative en termes de productivité (la productivité moyenne des traducteurs néerlandais étant plus de deux fois supérieure à celle de leurs homologues hébreux) et du nombre d'ouvrages traduits par auteur (le double sur le marché néerlandais). Ces écarts s'expliquent notamment par les disparités entre le contexte du marché de la traduction en Israël et celui des Pays-Bas et de la Belgique, mais aussi par la prédominance des subventions des États néerlandais et de la Communauté flamande pour la traduction dans les deux sens, bien que la politique de subvention ne soit pas la même pour chaque sens. De fait, il semblerait que l'on puisse tirer des conclusions importantes par l'analyse de facteurs tels que la taille et la répartition du corpus en ce qui a trait aux conditions de travail et aux subventions gouvernementales.
\end{abstract}

\section{ABSTRACT}

Literary translations from Hebrew into Dutch and vice versa between 1991 and 2010 are examined as a test case for cultural transfer between two peripheral languages, using a production of culture perspective (Peterson and Anand 2004). The findings show 138 Dutch books translated from Hebrew against 52 Hebrew books translated from Dutch. The data are analyzed by genre, translator's productivity, and number of books per author. The analysis reveals that both directions were similar in distribution of genres, but differed significantly in translator's productivity (the productivity of the average Dutch translator is more than twice as high as that of his or her Hebrew counterpart) and in the number of translated titles per author (twice as many in the Dutch market). The discussion traces these differences to the different structure of the translation labour market in Israel as compared to that of the Netherlands and Belgium and to the dominance of Dutch state subsidy and Flemish Community subsidy in both directions of the transfer, however with a different policy of subsidy in each direction. It seems that significant conclusions can be reached by examining such factors as size and distribution of the corpus on the backdrop of labour conditions and state subsidy.

\section{MOTS-CLÉS/KEYWORDS}

production culturelle, transfert culturel, politique de traduction, littérature néerlandaise, littérature hébraïque.

production of culture, literary transfer, translation policy, Dutch literature, Hebrew literature. 


\section{Introduction}

Focusing on two relatively small fields of literary translation - Dutch literature translated into Hebrew, and Hebrew literature translated into Dutch - this paper uses data characteristic of the production of culture perspective (Peterson and Anand 2004), which, following Bourdieu (1993), focuses on how symbolic goods are shaped by law and regulation, industry structure, or occupational careers; in our case, the overall size and internal distribution of the translated corpus, labour conditions for translators, and state subsidy (or the lack of it) in the respective markets. Arguably, especially in small, undeveloped fields like the intersections of the two peripheral literatures dealt with in this essay, such tools might be sufficient to account for much of the data even without having to resort either to more sophisticated Bourdieusian terms (applied to more central and complex markets, for example, Sapiro 2008 and 2010), or to elaborate studies of contents.

Using Heilbron's (1999) definitions of central, semi-peripheral and peripheral languages, Dutch and Hebrew clearly give an example of the latter: two peripheral languages and literatures, with no significant history of mutual relations. The overlap between them is small: very few Hebrew speakers read Dutch, very few Dutch speakers read Hebrew. Literary translation is therefore a major channel for cultural transfer between them. The narrowness of the channel has obvious limitations, but also an advantage for a case study: the scarcity of the data facilitates a comprehensive view. This essay focuses on the last two decades (1991-2010) of literary translation between the two languages - a period chosen rather arbitrarily, given that the two markets are too remote to present a common periodization - and attempts to give a quantitative description of each of the translation directions, and, by comparing them, suggest explanations for some of the more apparent differences. Arguably, many of these differences can be reduced to the professional environment of the translators on each side, and to economic factors, especially state subsidy.

The quantitative analysis concentrates on titles, translators, and authors. Sapiro, following Heilbron (1999) and especially Bourdieu (2008), convincingly stresses the need "to take into account publishers, whose role in the international circulation of books is crucial" (Sapiro 2008: 154). The present study has not done that, both because of the relatively small amount of data used, and, more importantly, due the scarcity of research on the Dutch and the Hebrew publishing industry in the relevant period. Here we need to clarify the use of certain terms: "Hebrew" is used for modern Israeli Hebrew (and its literature), not translations of any older Hebrew texts (specifically not of the Hebrew Bible, whose long translation history into Dutch need not concern us here). "Dutch" means the language of the Netherlands and of Flemish Belgium, and their literature. We shall focus on the dominant centre of the Netherlands, but make reference also to Flanders wherever possible.

Given that, in Toury's (1995: 29) words, "translations are facts of target-cultures," and given that cultural and economic relations are more often asymmetrical than not, comparing Dutch to Hebrew with Hebrew to Dutch translations needs a justification: Do these two apparently independent facts, one of the Hebrew culture, the other of the Dutch, have a common denominator? As we shall see later on, the common denominator emerges from the data. 


\section{Collecting the Data}

The first step was to collect data on translations from Hebrew into Dutch and vice versa. As Poupaud, Pym et al. (2009) show in detail, and as Sapiro (2010: 420) stresses, "a major problem when studying the market of translation is the lack of reliable data." Dealing with two peripheral languages, however, proved an advantage: the number of translated texts in both directions was rather small (scores, not hundreds), so that the data could be collected, checked and verified manually, item for item.

The scope was limited to books alone, in fact to books in the target language that were translated from the source language - directly or mediated by a third language - and published in the two decades between 1991 and 2010. This excluded publications in periodicals but included anthologies, even when prepared specifically for the target language. Also excluded were reprints of older translations (but new translations of previously translated works were included) and language textbooks. Collected data consisted of: author, translator, title (target language), title (source language), year of translation, information on subsidy. All Dutch translations were published in the Netherlands and/or Belgium; all Hebrew translations were published in Israel. An asymmetry presented itself even at this preliminary stage. Collecting data on Hebrew-to-Dutch translations proved an easy task; the opposite direction was considerably more difficult.

As for translations of Dutch literature, the Amsterdam-based Foundation for the Production and Translation of Dutch Literature (Nederlands Literair Productie- en Vertalingenfonds or NLPVF) ${ }^{1}$ maintains a database as well as a physical library of translations of Dutch texts into any language. The database is updated regularly and can be accessed freely via the internet. It includes full bibliographic records of both the translation and its Dutch source. To update the database, the NLPVF relies on informants - often translators - in the respective countries, who report to and purchase for it translations from Dutch that they come across. There are good reasons to believe that as far as translations from Hebrew into Dutch are concerned, the data, based on the NLPVF database, are virtually complete.

As for translations of Hebrew books into Dutch, the Israeli counterpart of the NLPVF is the Institute for the Translation of Hebrew Literature (ITHL) based in Israel. The ITHL website asserted that its Bibliographic Center comprised a computerized database of Hebrew literature in translation; it also publishes bibliographies of modern Hebrew literature in translation. The ITHL declined our request to share its database. Since June 2010 the website ended with the less felicitous note: "For information about translations from Hebrew literature to other languages: Service temporarily not available - our apologies." In the updated website launched in early 2013, this comment as well as any reference to a bibliographic database have been removed; at present (February 2013 - July 2014), using the "Advanced Search" option for Dutch yields just a handful of titles, probably those reviewed in the Institute's catalogues "New Books from Israel."2 The Institute's Bibliography of Modern Hebrew Literature in Translation was consulted; however, its last volume appeared in 1994.

Apparently no other Israeli organ systematically collects data on all translations of Hebrew literature, so Dutch sources had to be relied on. Here, too, no catalogue or bibliography of translated titles seemed to exist. The Dutch Royal Library runs the Netherlands Bibliography which includes descriptions of all the works published in 
the Netherlands since 1974: however it depends on the good will of the publishers and does not actually receive all Dutch language publications, and definitely not those from Belgium. To complete that catalogue, several other Dutch catalogues were consulted, as well as other resources like Index Translationum and WorldCat. None of them lists translated works separately, let alone translations from a specific language.

Therefore, the data had to be collected in a heuristic manner. The best search method proved to be by translator's name: translators from Hebrew into Dutch are few, and browsing the various catalogues by their names yielded most of the titles. For other books, especially mediated translations, searching by the author's name was also fruitful. Casual searches of well-known Israeli writers in various Dutch catalogues helped complete the picture, as well as personal communications that were checked against the various Dutch catalogues.

\section{Titles and Categorization}

In the Hebrew to Dutch translation direction, between 1991 and 2010, 138 titles translated from Hebrew were published in Dutch. Five of them were explicitly translated indirectly (via English). The five-year distribution was rather stable: 32 (19911995), 43 (1996-2000), 32 (2001-2005), and 31 (2006-2010). Divided into four categories by genre, $100(72.4 \%)$ of the titles were fiction, 20 (14.5\%) nonfiction, $18(13.0 \%)$ children's books, and none were poetry. In the Dutch to Hebrew translation direction, in the same period of time, 52 books translated from Dutch were published in Hebrew. Four of them were explicitly translated indirectly via English. The five-year distribution was six (1991-1995), eight (1996-2000), 14 (2001-2005), and 24 (2006-2010), showing a significant rise. Divided into four categories, 32 (61.5\%) of the titles were fiction, ten (19.2\%) nonfiction, eight (15.4\%) children's books, and two (3.8\%) poetry.

The absolute numbers of titles, considered by themselves, say very little. Clearly, the Hebrew-to-Dutch channel was 2.6 times richer than the opposite direction; but what does this mean? One can think of quite a few alternative or perhaps complementary backdrops on which the data can be interpreted: economic, considering the respective GNP, the size of the book industry and similar parameters; demographic, considering the size of the relevant readers' population; cultural, considering the interest Dutch readers have in Israeli culture and vice versa; literary, considering the status of translated literature within the respective target literary system, and considering the status of the respective national literature in the global literary system; thematic, considering for example the role of Jewish themes in translations into Hebrew; aesthetic - perhaps Hebrew writers are "simply better" than the Dutch? No simplistic interpretation will be offered here.

As for the category distribution, translations in both directions show a rather similar pattern, with fiction accounting for roughly two-thirds of the titles, the rest divided more or less equally between children's books and nonfiction. There is also a very small number of poetry titles on one side. Again, a wider database might be revealing for the interpretation of this similarity. 


\section{Translators}

In the Hebrew to Dutch translation direction, there were 26 different translators, which gives an average of 5.3 books per translator. The most productive translators (with more than 10 titles each) were Ruben Verhasselt with 44 titles, Hilde Pach with 20 titles, Shulamith Bamberger with 18 titles, and Kees Meiling with 18 titles (the next most productive translator had just seven titles). Taken together, these four translators produced $72.5 \%$ of all translated titles. As for the period of activity, one of these four most productive translators (K. Meiling) was active for 19 years, the other three were active during the entire two decades; this means that on average, each of them was active for 19.8 years of the research period, with a negligible standard deviation of 0.5 . In the Dutch to Hebrew translation direction,the number of different translators was 25 , which gives an average of just 2.1 books per translator. Relatively productive translators (with more than three titles each) were Ran HaCohen with nine titles, Carla Perlstein and Inbal Silberstein with six titles each, and Shulamith Bamberger with four titles. Taken together, these four translators produced $48.1 \%$ of all translated titles. On average, these four most productive translators were active for 8.3 years, with a very high standard deviation of 3.8.

The two pictures differ dramatically. Though the absolute number of translations into Dutch was 2.6 times larger than into Hebrew, the number of translators into Dutch was approximately the same. The average Dutch translator produced more than twice as many books than his or her Israeli colleague.

This major difference is indicative of the different structure of the respective translation market. The Dutch market is dominated by full-time literary translators, for whom translation is their main occupation. They are few, but they work for decades and are highly productive. The Israeli market is based on casual translators, for whom translation is a secondary job; many of them translate a book or two, and disappear. A central translator into Hebrew, Shulamith Bamberger, ${ }^{3}$ is an illuminating case: the native Hebrew-speaker moved to the Netherlands as a young adult, and translates in both directions. However, in the research period she translated just four books into Hebrew - her native tongue - compared with the 18 titles she translated into Dutch. Even in this case, then, translation into Dutch was her main occupation, whereas translation into Hebrew was secondary. Similarly, even Ran HaCohen, the most prolific translator into Hebrew in the research period, earned his living primarily not as a translator but as a university teacher.

The reason for this difference between the Dutch and the Israeli translation market is economic, and it applies to the Dutch and to the Israeli markets in general, independent of the source language. In a nutshell, one cannot earn a living from literary translation into Hebrew. Even the very few most prestigious literary translators usually have an additional source of income (as literary editors or other), and most Israeli translators apparently translate as a secondary, part-time or temporary job, or rely on another source of income (their own or their partner's; most translators are women). As Venuti (1995: 11) wrote about English-language translators in the postwar period, "below-subsistence fees force them [...] to translate sporadically, while working at other jobs (typically editing, writing, teaching)." Translating into Dutch, on the other hand, is a viable economic option. Surprisingly, perhaps, we shall now see that the difference in translation fees between Israel and the Low Countries is not the main reason for this. 
In Israel translation fees, like all other terms and conditions of the contract between publisher and translator, were negotiated individually between the two parties; each publishing house had its own contract. The Israel Translators Association [Agudat ha-metargemim be-Yiśra'el] is powerless. As a rule, the translator - working on a freelance basis - was in an inferior position vis-à-vis the publishing house. Minimum translation charges recommended by pertinent organs were in circulation, but had very little effect on the actual fees paid. Though no reliable information could be obtained, ${ }^{4}$ we estimate that in 2010 the average charge for translation from Dutch into Hebrew was around $0.30 \mathrm{New}$ Israeli Shekel (€0.06) per word of the translated text, with a wide margin of give or take, probably about 20\%. (This charge was considerably higher than for translations from English.) No royalties were paid for sold copies or reprints, and the translator irreversibly sold to the publisher all his or her rights to the translation.

Things are more regulated in the Netherlands, where translation is more of a profession than semi-profession (or pastime; no value judgement implied) that it is in Israel. ${ }^{5}$ Since 1977 there is an elaborate, 13-page long "model contract" for literary translations agreed upon between the Dutch Trade Publishing Group (Groep Algemene Uitgevers or GAU) and the Dutch society of authors (Vereniging van Letterkundigen or $\mathrm{VvL}) .{ }^{6}$ The translator - freelance here too - retains some of the rights to the translation, and the contract is not irreversible. For example, if the publisher fails to reprint an out-of-print translation, the translator may terminate the contract (and sell the translation once again, to another publisher). The two organs (GAU and $\mathrm{VvL}$ ) also negotiate a recommended minimum charge for literary translation (from any language) into Dutch. Though in no way obligatory, both the model contract and the recommended minimum charge are widely used. In 2010, the charge was $€ 0.063$ per word of the translated text ( $€ 0.062$ since January 2009 , indexed); royalties were paid above 2,500 copies sold.

Translators into Dutch thus enjoy more rights and better terms than their colleagues translating into Hebrew. However, the main component of the translator's income being the translation fee (especially in marginal literatures, where bestsellers are so seldom that royalties are not a major factor), the difference between the two markets is quite small, ${ }^{7}$ and cannot account for the great difference in the professional constellation. The missing factor that does explain this difference is state subsidy.

In Israel, state subsidy does not play any role in this section of the market. The Mofet Project [Ha-mif'al le-tirgum sifre mofet] - financed by the Ministry of Culture and supporting translations of quality literature - did not support any translation from Dutch in the research period (and neither before nor after this period to this date).

A significant player in the Dutch-to-Hebrew translation market was the Dutch NLPVF and its Belgian counterpart, the Flemish Literature Fund (Vlaams Fonds voor de Letteren or VFL). Each of these foundations - the NLPVF for Dutch works from the Netherlands, the VFL for works from Flemish Belgium - helped the foreign (here: Israeli) publisher by subsidizing $70 \%$ of the translation costs (in some cases even more). The subsidy was paid directly to the publisher, and it enabled publishers to pay translators from Dutch more generously, though not above the Dutch standard: the foundations would not subsidize a higher fee. ${ }^{8}$ Though the Israeli publisher was financially stimulated by the Dutch (and Flemish Community) state subsidy, the 
translator into Hebrew had to rely exclusively on the publisher for all of his or her income. ${ }^{9}$

No Israeli subsidy was available for translators into Dutch. ${ }^{10}$ However, translators into Dutch worked under radically different circumstances: they could apply for a state subsidy in addition to the fee (and royalties) from the publisher. Subsidies were granted by the Dutch Foundation for Literature (Fonds voor de Letteren or FvdL), ${ }^{11}$ which, according to a personal communication from a Dutch translator, ${ }^{12}$ practically assured that an average literary translator working on average literary texts from any language was able to make a decent living (by comparison, this was not the case even with top translators into Hebrew). ${ }^{13}$ In order to apply for a grant, the translator must have had a first book published by a commercial publisher. This first translation was submitted to the Dutch Foundation for Literature for evaluation. Starting from the second translation, the translator could apply for a grant for every translation project (the only limit being the translator's total annual income). Grants were paid directly to the translator, in addition to the translation fee paid by the publisher; in fact, the grant was very often higher than this fee. To prevent exploitation of the translator, no grants were given to projects that did not meet the minimum conditions set by the model contract (see note 7), or in which the translator's fee was lower than the recommended minimum charge; with this regulation, the state in fact backs and corroborates the agreements between the translators' union and the publishers' association.

Since Hebrew is a small language and its (few) translators into Dutch (as well as their translation projects) are all considered to be of high quality, practically every application for a translation project from Hebrew was confirmed. ${ }^{14}$ Actual grants were dependent on the literary quality of the book, the complexity of the translation and the translator's skill, but the average grant (at the end of the research period) was $€ 2,500$ per 30,000 words ${ }^{15}$ representing $€ 0.083$ per word $-131 \%$ more than the minimum translation charge. For the three translations from Hebrew supported in 2010 , the average grant was about $€ 11,000$ per title. ${ }^{16}$ Such major support, more than doubling the translator's income, encouraged professional literary translators to devote themselves fully to their work and enabled them to make a decent living as translators (the situation in Flemish Belgium is similar, being modeled on the Netherlands). If a single factor is sought to explain the great difference in the Dutchto-Hebrew translator's profile from that of Hebrew-into-Dutch, it was state subsidy - or the lack of it - and the identity of the beneficiary of this subsidy.

\section{Translated Authors}

In the Hebrew to Dutch translation direction, the total number of Hebrew authors translated was 62, which gives an average of 2.2 translated titles per author; the most translated authors were Amos $\mathrm{Oz}$ with 14 titles, David Grossman with 13 titles, and Me'ir Shalev with 12 titles, followed by A.B. Yehoshua (eight titles), Uri Orlev, and Aharon Appelfeld (five titles each). Taken together, these six eminent writers were responsible for $44.9 \%$ of all the titles. Nine authors had two titles translated; 39 authors had only a single title translated. The titles of these less-translated authors (one or two titles) in total made up $37.7 \%$ of all titles. In the Dutch to Hebrew translation direction, the total number of Dutch authors translated was $45,{ }^{17}$ which gives 
an average of just 1.2 titles per author. Only one author, Anna Enquist, had three titles translated. Five authors had two titles translated; the other 39 authors had just a single title. Taken together, titles of these less-translated authors (one or two titles) made up $94 \%$ of all translated titles.

As with the translators, the two pictures are dramatically different. Note that this difference has far-reaching literary and even cultural implications. The Dutch readers are not just exposed to more titles translated from Hebrew: they are exposed to a meaningful selection of Hebrew titles. From the literature on offer in bookshops and libraries, readers can distinguish between canonical, "major," "important" or "established" writers like Amos Oz or David Grossman, of whom more than a dozen titles are available in Dutch, "less important" or younger writers like Shifra Horn or Alon Hilu, of whom a few titles are available, and "minor" or beginning writers like Asaf Gavron or Eleonora Lev, of whom just a single title is available. Needless to say, no 138 titles can be truly representative of the Hebrew book market as it is conceived in Israel, nor does it have to be: some writers may be better suited for Dutch readers, others may be neglected or over-represented for a myriad of reasons. The point is that the image of Hebrew literature in Dutch, as it is represented by the translated titles, is differentiated. In fact, the most translated authors are indeed considered major writers in Israel as well, and many of the one-title authors are also considered minor in their source culture. The established authors make up almost half of the titles, about a third of the titles are occupied by lesser-known writers, enabling the publishers to experiment and look for the next promising Hebrew writers for the Dutch market, and the rest of the authors occupy an intermediate position between the established and the new.

This is in no way the case with the selection of Hebrew translations from Dutch. As we have seen, $94 \%$ of the Dutch titles were by authors with just one or two titles translated. Based on what is offered in bookshops and libraries (and derivatives like literary reviews, etc.), Hebrew readers cannot form any reliable image at all of what Dutch literature might look like. Seen from Israel, the Netherlands and Flanders have many writers, but there is no way to establish a hierarchy among them, since each of them appears in the Hebrew market with a title or two and then vanishes. Except for Anna Enquist, there was no such thing as an "established" Dutch writer in Israel. ${ }^{18}$

To illustrate this, let us take the "Great Three" Dutch writers of the post-WW2 generation: W.F. Hermans (1921-1995), Harry Mulisch (1927-2010), and Gerard Reve (1923-2006). Of these three, only a single book of Mulisch was translated in the research period - alongside 49 other books of less canonical writers (and one translation of Multatuli, the $19^{\text {th }}$ century classic). Even if we add two earlier Hebrew translations of Mulisch published in the 1980s, and the single translation of Hermans published in 2011, all we get is three titles by Mulisch, one by Hermans and none by Reve, compared to, say, three titles by Anna Enquist, two by Marcel Möring, or two by Arthur Japin, all of whom are considered much less central Dutch writers than the "Great Three."

How can this difference be explained? There is no denying that the publishers' selection of titles to translate is a complex process and depends on many factors, which cannot be dealt with here. Specifically, thematic considerations are consciously left out of this paper. However, we would like to argue that the radically different pictures in the Netherlands/Flanders and in Israel are reducible to one factor which is, once again, state subsidy. 
We have already seen the impact of state subsidy on the translator's profession. This may in turn have consequences for the selection of titles as well. In the Netherlands, the small cadre of professional translators from Hebrew function de facto as experts in Israeli literature, who use their immediate acquaintance with the Hebrew literary market to recommend Israeli authors and titles to the Dutch publishers. In Israel, on the other hand, translators from Dutch cannot fully professionalize, and since no Israeli university offers "Dutch Studies" in any form whatsoever (the most one can find are beginners' courses for Dutch as a foreign language), there are simply no Hebrew-speaking experts for Dutch literature. Israeli publishers must therefore rely on proactive Dutch PR efforts (probably oriented more towards recent texts than towards classics), on English translations, and on chance and gut feelings - a possible explanation for the haphazard selection of translated titles. But this is not the whole explanation.

Let us return now to state subsidy. First, a short look at the extent of these subsidies: of the 52 Hebrew translations, $27 \%$ or $51.9 \%$ were subsidized by the Dutch NLPVF or by the Flemish VFL. Leaving out the four mediated translations, which could not be subsidized, the subsidy rate was $56.3 \%$. The first Hebrew title to be subsidized appeared in 1997; counting only later titles, the subsidy rate reached $61.3 \%$; and for the last decade, 2001-2010, the rate was even higher: $67.5 \%$ of all Hebrew translations from Dutch were subsidized. Many of the non-subsidized books were children's books with little text, where translation costs were marginal. In short, a large majority of Hebrew translations were published with Dutch or Flemish subsidy, and since not all applications were actually granted, we can safely assume that the prospect of getting a subsidy played a role in the publisher's selection even when it did not materialize.

In fact, the very rise we have noticed in the number of translations into Hebrew could be explained by the appearance of the NLPVF as a player in Israel in 1997; Chart 1 also includes data on earlier years, which seem to support the assumption

CHART 1

Hebrew Titles Translated Directly from Dutch, 1985-2010

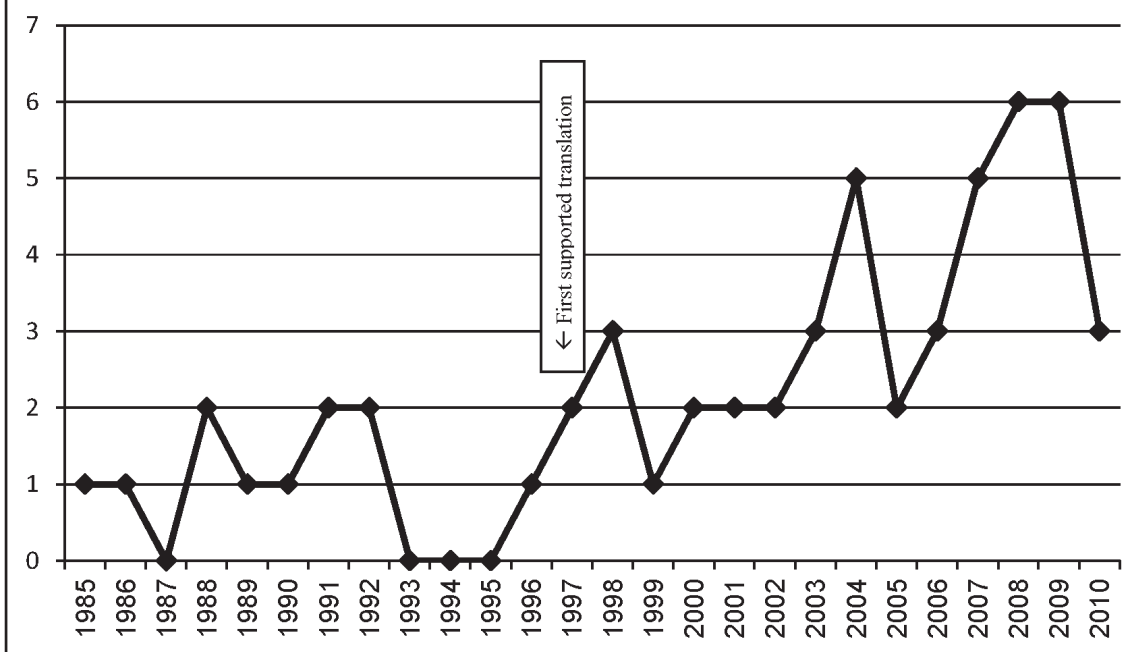


that the rise started at that time. Another factor - not independent of the Foundation's work, though - may have been the 1993 Frankfurt Book Fair, where Dutch and Flemish literature was the focal theme, which gave rise to translations from Dutch into many languages (see Heilbron 1999: 437.

As for translations from Hebrew into Dutch, data could be obtained, regretfully, only for the last decade (2001-2010), ${ }^{19}$ but they were indicative enough. Of the 60 books published in that decade, only 27 were published without a Dutch (or Flemish) grant.Seven of these unsupported titles were children's books with little text. This means that also in this direction, from Hebrew into Dutch, the large majority of titles - about two-thirds - enjoys Dutch state support.

We now see that the entire phenomenon dealt with in this essay - literary translations both from Dutch into Hebrew and vice versa - was dependent on what recently became one Dutch foundation located in Amsterdam, the Dutch Foundation for Literature, and, to a lesser extent, on its Flemish counterpart in Antwerp/ Berchem, the Flemish Literature Fund. But while there was ultimately a single purse behind the apparently two independent literary transfers - the Dutch (and Flemish) state budget - the support policy in each of the two directions was quite different. Arguably, a careful look at these policies will help us understand why the pictures were so radically different.

As already noted, in the Netherlands two separate foundations were responsible for the subsidies: the NLPVF subsidized translations of Dutch literature into foreign languages, whereas the FvdL supported translators from foreign languages into Dutch. Each of these foundations (since 2010, departments of the Dutch Foundation for Literature) had a different support policy. ${ }^{20}$ The different policies were due also, but not exclusively, to the different resources available to each foundation. For example, in 2008 the FvdL and its Flemish counterpart spent about $€ 2,000,000$ on subsidies for translators into Dutch, whereas the NLPVF spent a much smaller amount, $€ 652,741$, on translations subsidies from Dutch, and the Flemish counterpart probably spent significantly less. ${ }^{21}$ The different spending reflects a prioritisation which in turn, at least in the case of the Netherlands, was explicitly stipulated in a policy paper submitted to the government a few years before the period surveyed in this article (1987), recommending that the Kingdom's

principal aim of international cultural policy should be to strengthen the international position of cultural expression in the Netherlands as part of general policy on cultural matters. A subordinate aim could be to play a specific role in support of foreign policy. ${ }^{22}$

The NLPVF policy stipulated that only the first two translations of any author could be subsidized; after these two, the foreign publisher, that is, the beneficiary of the support, should finance further translations without subsidy. There are certain workarounds to this limitation, such as publishing a book of another genre by the same author, but they are seldom feasible and Israeli publishers are generally aware of them. The FvdL policy of supporting translations into Dutch had no such limitation: translators (the beneficiaries) could apply for a grant for as many projects as they liked, be it of the same or of various authors.

The selection of titles in each direction clearly reflects these different policies. An Israeli publisher eager for subsidy had little incentive to publish more than two books of the same author, unless they were successful to the extent that the market 
compensates for the lack of subsidy, which was very rare. Indeed, there was just a single Dutch author, Anna Enquist, who reached a third, non-subsidized book in Hebrew, due to the commercial success of her first two novels in Israel. In fact, two more Hebrew titles of hers are in press. In all the other cases, the Israeli publisher produced a subsidized title or two and then moved on to another author that could be subsidized. This seems to be a major reason why $94 \%$ of the translations from Dutch into Hebrew were by authors with just one or two titles: only such translations were candidates for subsidy.

There was no restriction of this kind on translations into Dutch. Furthermore, it was the translator, not the publisher who was supported: the subsidy did not play any role in the publisher's selection, since the publisher could not expect the subsidy. This yielded a very different selection: publishers translated many titles of wellknown, established and likely-to-sell authors, balanced by a significant number of lesser known authors who were still considered worthwhile, and by a number of newly introduced writers. Dutch publishers had no reason to count an author's previously translated titles while considering translating another of his or her titles; the lack of this arbitrary restriction yielded a richer and a more balanced selection and created a hierarchy, making it more representative of the source literature.

\section{Conclusions}

There was a quantifiable asymmetry in the cultural transfer between the two peripheral languages Hebrew and Dutch, expressed in the number of translated titles, in the productivity of the average translator, and in the average number of translations per author. It would be tempting to assume that this asymmetry was the result of dealing with two independent phenomena; in fact, the opposite seems to be the case. Cultural transfer in both directions was highly dependent on Dutch and Belgian subsidy; but in each direction the subsidy was given according to a different policy. Whereas support for translations into Dutch encouraged professional, full-time translators and yielded a rich and differentiated literary transfer, the support for translations from Dutch was not able to create a cadre of full-time translators into Hebrew, and resulted in a low number of titles per translator, a low number of translated titles per author, haphazard selection, and a senseless image of Dutch literature in Hebrew.

In more general terms, this case study shows that the source culture might in some cases play a more significant role in literary transfer than is often assumed (see Amit 2007), to the extent that both directions of the literary transfer can be dominated by the stronger party; and that labour relations and state subsidy can be decisive elements in explaining actual literary transfer. Furthermore, what at first sight might look flattering to the one culture (the fact that many more Hebrew titles are translated into Dutch than vice versa) might on second sight reflect its weakness (in terms of low investment in literary transfer). The stronger culture not only invests significantly higher resources in literary transfer, both in export and in import, but by doing so, it also sets its own priorities: in this case, it is more interested in enriching its own readers with foreign literature than in enriching foreign readers with its own. Is this a unique case (given the exceptionally generous Dutch system of subsidies) or do other, especially asymmetrical cases, behave in a similar way? Further research is needed to find out. 
On a theoretical level, two apparently separate, peripheral fields of literary translation, with hardly any theoretical justification for analyzing both of them together, have been shown to be strongly interrelated in the sense of both having a common organizing factor. Furthermore, several central characteristics of each of the fields and their respective products (translated corpora), with significant cultural and literary implications, have been accounted for. All this has been achieved merely by looking at parameters from the production of culture perspective, especially the size and distribution of the translated corpora, regulation and state subsidy, and occupational careers.

\section{NOTES}

1. The NLPVF was set up in 1991. Since January $1^{\text {st }}, 2010$ it is part of the Dutch Foundation for Literature (Nederlands Letterenfonds), based in Amsterdam. See Kostine (2000) and Ministry of Education, Culture and Science (2006): Cultural Policy in the Netherlands. Amsterdam: Boekmanstudies, 104.

2. The Search and the Catalogues are at http://www.ithl.org.il/home.aspx (visited 28 July 2014). While preparing this article for print, ITHL expressed its readiness to share its relevant database in the near future (librarian Eliahu, Rachel, e-mail communication, 29 July 2014), but it was too late to wait.

3. Bamberger is by far the longest active translator from Dutch into Hebrew: she had already translated several titles by the late 1970s that fall outside the research period of this paper. She resumed her translation activity into Hebrew in 2002 after a long break.

4. Even the unit of measurement is not standardized. Though most publishers count by "printer's sheet," some define it in words (usually 4,500 Hebrew words per sheet) whereas others count characters (24,000 per sheet); but some publishers do not count the spaces (about $20 \%$ of the characters).

5. An effective professional organization is considered a central feature of a profession; see Weiss-Gal and Welbourne (2008) and Dam and Zethsen (2010).

6. The model contract can be viewed at http://www.letterkundigen.nu/vvl/media/original/93/190612_ lug_vvl_modelcontract_literaire_vertalingen_en_toelichting.pdf (visited 28 July 2014).

7. Fees are compared according to their nominal values, ignoring differences in the cost of living between Israel (where most translators into Hebrew reside) and the Low Countries (where most translators into Dutch live). Also unconsidered is the fact that due to orthographic conventions, translation from Dutch to Hebrew reduces the number of characters in a text while translation in the opposite direction increases it.

8. The NLPVF also alerts foreign publishers who pay their translators too little. Since 2007, the limits of subsidized translation fees are normalized according to living costs per country. See NLPVF Jaarverslag 2007, 26. Visited 28 July 2014, <http://www.letterenfonds.nl/dl.php?file=22 >.

9. Both the NLPVF and the VFL employ another channel to support translators directly: by hosting them in their Translators' Houses, in Amsterdam and in Antwerp (previously in Leuven). This is a major bonus, enabling active translators to stay up to two months a year in a Dutch speaking environment.

10. The ITHL supports translations of Hebrew literature, but could not give information on support for translations to Dutch; as far as we know, it has never supported any such translation.

11. The Fonds voor de Letteren was set up in 1965. Since January $1^{\text {st }}, 2010$ it is part of the Dutch Foundation for Literature (Nederlands Letterenfonds), based in Amsterdam. See Ministry of Education, Culture and Science (2006): Cultural Policy in the Netherlands. Amsterdam: Boekmanstudies, 103.

12. Bergsma, Peter (August 2011): personal communication, Translators' House, Amsterdam.

13. A subsidized translator in the Netherlands had in 2008 an average annual income of $€ 19,000$; it enabled translators to deliver good quality translations, though it was lower than the average salary. HaAn, Martin de and Hofstede, Rokus (2008): Overigens schitterend vertaald. Voor het behoud van een bloeiende vertaalcultuur. Amsterdam/Brussel: Dutch Language Union etc., 14. Visited 28 July 2014, <http://www.vertaalpleidooi.nl>.

14. Swarttouw, Anne (August 2011): personal communication, Dutch Foundation for Literature. 
15. Fonds voor de Letteren. Visited 28 July $2014,<$ http://www.fondsvoordeletteren.nl/mod.php? $\bmod =$ userpage\&page_id=53\&menu=370001 $>$.

16. All grants are listed in detail in the Foundation's annual reports: http://www.fondsvoordeletteren. nl/mod.php?mod=userpage\&page_id=61\&menu=4107 (visited 28 July 2014).

17. An anthology of Dutch poetry was counted as one author. Arnon Grunberg and his pseudonym Marek van der Jagt were counted as one author.

18. The best known Dutch writer in Israel is probably Anne Frank; even during the research period, her Diary was translated twice. Her exceptional position, however, is obvious.

19. Older annual reports could not be found due to the recent relocation of the Foundation's archives.

20. In Belgium the two directions were always subsidized by the same foundation, the VFL; its policy of supporting translations into Hebrew is practically identical to that of the Dutch NLPVF.

21. GraAfF, Onno de (October 2011): personal communication, NLPVF. The sum for the FvdL and FVL was taken from HaAn, Martin de and Hofstede, Rokus (see note 13).

22. Netherlands scientific Council for Government policy (1987): Culture and Diplomacy. Thirty-first Report to the Government. The Hague: NSCGP, 5. Visited 28 July 2014, <http://www. wrr.nl/fileadmin/en/publicaties/PDF-Rapporten/Culture_and_diplomacy.pdf>; our emphasis).

\section{REFERENCES}

Aмiт, Yuval (2007): Yetzu shel tarbut yiśre'elit, pe'ulatam shel mosadot rishmiyim be-targum sifrut me-ivrit le-anglit [The Export of Israeli Culture: The Role of Formal Institutions in the Translation of Hebrew Literature to English]. Doctoral thesis, unpublished. Tel Aviv: Tel Aviv University.

Bourdieu, Pierre (1993): The Field of Cultural Production. (Edited by Randal Johnson). New York: Columbia University Press.

Bourdieu, Pierre (2008): A conservative revolution in publishing. (Translated by Ryan Fraser). Translation Studies. 1(2):123-153.

Dam, Helle V. and Zethsen, Karen Korning (2010): Translator Status: Helpers and Opponents in the Ongoing Battle of an Emerging Profession. Target. 22(2):194-211.

Heilbron, Johan (1999): Towards a Sociology of Translation. Book Translations as a Cultural World-System. European Journal of Social Theory. 2(4):429-444.

Kostine, Sonja (2000): An Analysis of the Factors that Influence the Translation and Sale of Dutch Literature to Great Britain. Postdoctoral dissertation. Rotterdam: Erasmus University.

Peterson, Richard A. and AnAnd, Narasimhan. (2004): The Production of Culture Perspective. Annual Review of Sociology. 30:311-334.

Poupaud, Sandra, Pym, Anthony and Torres Simón, Ester (2009): Finding Translations. On the Use of Bibliographical Databases in Translation History. Meta. 54(2):264-278.

SAPIRO, Gisèle (2008): Translation and the field of publishing. A commentary on Pierre Bourdieu's "A conservative revolution in publishing." Translation Studies. 1(2):154-166.

SAPIRO, Gisèle (2010): Globalization and cultural diversity in the book market: The case of literary translations in the US and in France. Poetics. 38:419-439.

Toury, Gideon (1995): Descriptive Translation Studies and Beyond. Amsterdam/Philadelphia: John Benjamins Publishing.

Venuti, Lawrence (1995): The Translator's Invisibility: A History of Translation. London/New York: Routledge.

Weiss-Gal, Idit and Welbourne, Penelope (2008): The professionalisation of social work: a crossnational exploration. International Journal of Social Welfare. 17:281-290. 